\title{
SIMPLIFIED APPROACHES FOR MODELING INFILLED FRAMES
}

\author{
MihaelaTeni \\ Josip Juraj Strossmayer University of Osijek, Faculty of Civil Engineering Osijek, mag.ing.aedif. \\ Marin Grubišić \\ Josip Juraj Strossmayer University of Osijek, Faculty of Civil Engineering Osijek, mag.ing.aedif. \\ Corresponding author: marin.grubisic@gfos.hr \\ Ivica Guljaš \\ Josip Juraj Strossmayer University of Osijek, Faculty of Civil Engineering Osijek, Associate Professor
}

\begin{abstract}
In many seismic areas, reinforced-concrete frames are filled with masonry infill walls. The behavior of these structural composite systems are difficult to model, and existing regulations lack guidelines for their design. In most cases, the masonry infill is excluded from the design process because it is considered a non-structural element. However, excluding them can have significant negative consequences. A properly modeled and designed reinforced-concrete frame with infill can significantly affect the strength, stiffness, and energy dissipation of the frame structure. In fact, a masonry infill combined with a relatively flexible reinforced-concrete frame certainly takes part in the resistance to horizontal actions. To investigate this issue, we modeled the behavior of frame structures with masonry infills in three ways: First, we used a linear seismic method of equivalent horizontal forces, applied to six models with different heights, modeling the masonry infill with "shell" finite elements. Second, we performed the same analysis with a "link" element as a compressive strut. Third, we used nonlinear dynamic analysis to consider the concentrated plasticity of columns and beams and a nonlinear model with the masonry infill considered a compressive strut. In each modeling approach, the masonry infill significantly affected the behavior of the structures and their dynamic response to seismic actions.
\end{abstract}

Keywords: infilled frames, masonry infill, numerical modeling, linear and nonlinear analysis, CSiSAP2000

\section{POJEDNOSTAVLJENI PRISTUPI MODELIRANJU OKVIRA S ISPUNOM}

Sažetak: U mnogim zemljama i seizmičkim područjima, armiranobetonski okviri ispunjeni su zidanom ispunom, tako predstavljajući konstrukcijski kompozitni sustav čije ponašanje je teško predvidjeti i modelirati, što vodi do nedostatka smjernica za projektiranje u postojećim propisima. Zidane ispune najčešće se smatra nekonstrukcijskim elementom te se redovito ne uključuju u proračun, što može imati znatne negativne posljedice. Dokazano je da pravilno modeliran i projektiran armiranobetonski okvir s ispunom ima bitan utjecaj na čvrstoću, krutost i disipaciju energije okvirnih konstrukcija. Naime, smatra se da zidana ispuna, u kombinaciji s relativno fleksibilnim armiranobetonskim okvirima, zasigurno preuzima jedan dio otpornosti na horizontalno djelovanje. S obzirom na ovu problematiku, provedena su tri načina modeliranja ponašanja okvirne konstrukcije sa zidanom ispunom. Prvi pristup je linearna seizmička analiza metodom ekvivalentnih sila na šest različitih modela po visini, te dva načina modeliranja zidane ispune - pomoću "shell" konačnih elemenata te pomoću "link" tlačne dijagonale, programom CSi SAP2000. Drugi pristup obrađuje nelinearnu dinamičku analizu s koncentriranim plastičnostima za stupove i grede te nelinearni model tlačnih dijagonala za zidanu ispunu. Zaključeno je da zidana ispuna u svakom pristupu modeliranja bitno utječe na ponašanje konstrukcije i dinamičke karakteristike pri potresnim djelovanjima.

Ključne riječi: okviri s ispunom, zidana ispuna, numeričko modeliranje, linearna i nelinearna analiza, CSi SAP2000 


\section{INTRODUCTION}

\subsection{Aim of the study}

In this paper, we present and compare three of the simplest (Table 1), most intuitive approaches for modeling infilled frame structures with an advanced commercial program. These models include certain simplifications and limitations, so we focus on comparing and contrasting them, discussing how they relate to real behavior.

\subsection{Overview of infilled frames}

Reinforced-concrete frames with masonry infills are structural systems that are often used in areas of high seismicity. Though masonry infills are widely used as the interior partitions and exterior walls of buildings, they are usually considered non-structural elements and are not included in modeling during the design process because current regulations give no clear, direct guidelines for their design, even though they are still built into buildings. Recent studies have shown that using a properly modeled and designed reinforced-concrete frame with an infill greatly benefits the strength, stiffness, and energy dissipation of frame structures [1-6]. Because a masonry infill greatly changes the behavior of the frame during earthquakes, it is important to include its effects in the design process. In fact, a masonry infill combined with a relatively flexible reinforced-concrete frame certainly increases the resistance to horizontal actions. Different types of infills certainly affect structural resistance, which depends mostly on the quality of the mortar and the masonry elements (most commonly hollow clay and solid brick units), so they are often categorized into "weak" and "strong" masonry infills.

Infilled frames can have both positive and negative effects [7] that cannot be reliably accounted for [8]. A masonry infill can significantly increase the strength and stiffness of the frame structure for a continuous, uniform distribution of infill walls. In contrast, plastic deformations can occur in unequal distribution of infill walls, which can hinder the behavior and safety of the building. Besides the global plastic deformations of the frame, a masonry infill can also cause negative local effects, which can lead to premature brittle structural failure. Also, adding a masonry infill can cause the system to respond in elastically and predispose it to inelastic deformation if the contribution of the infill to the horizontal strength and stiffness is significantly greater than the strength and stiffness of the bearing system. In this case, at high deformation the frame and infill can lose integrity, and cracks can develop in the ground floor, which can cause a soft storey to form or cause the frame elements to suddenly collapse.

Table 1 The basic characteristics of linear and nonlinear numerical models

\section{LINEAR MODELS}

- Simpler models

- All materials comply with Hooke's Law

- Few input parameters

- Assessment of the global structural behavior

- Faster calculation

- Convergence is not a problem in dynamic analyses

\section{NONLINEAR MODELS}

- Complex models

- Many input parameters

- Assessment of the structural elements behavior

- Slower calculation

- Possible convergence problems in dynamic analyses

- Needed if the loading produces a significant changes in the stiffness

- Important if large displacements change the geometry

The national regulations of most countries do not specify design procedures for masonry infills, considering themnon-structural elements. According to Eurocode 8 (EC8), non-structural masonry infills in earthquakeresistant buildings area "second line of defence" and increase the capacity. EC8 does not make it necessary to reduce the seismic resistance of the structure during design because it considers the masonry infill to have only positive effects; the additional resistance caused by the masonry infill is considered "stocks of resistance". In EC8, masonry infills are required when a structure is designed for relatively low stiffness and load capacity, but high ductility. 
The greatest problem in seismic analysis of reinforced-concrete frames is the uncertainty arising from the nonlinearity of the masonry infill. The behavior of these systems can be properly modeled by thorough analysis, materials testing, and nonlinear modeling. So far, numerical modeling of frames with infills can be divided into complex "micromodels" and simple, more engineering-focused "macromodels". An important micromodel is the finite element method, while an important macromodelis the equivalent strut diagonal. Eurocode 8 does not provide detailed guidance for modeling masonry infilled frames, and it focuses more on the possible negatives that can of such structures than on the positives.

While the failure mechanisms of masonry infilled frames cannot be correctly predicted by the linear micromodelsor nonlinear macromodels used in the present study, the details of possible failure mechanisms can be found elsewhere [9-12].

\section{MODEL DEFINITION AND LOAD ANALYSIS}

In this paper, we describe and analyze possible simpler models of how masonry infills affect the behavior of reinforced-concrete frames. We selected a regular reinforced-concrete structure for the numerical models, a building that has a corresponding real prototype [13]. All the models have the same floor plan and area, but different heights: 4,7 , and 10 storeys. The ground storey has a height of $3.75 \mathrm{~m}$, and the other storeys each have a height of $3 \mathrm{~m}$. The columns and T-beams of all models have the same square cross-sections. For all models, the position of the masonry infill was also varied to be either only the central bay or the external bays. All models experienced the same vertical load on the structure and used the same materials.

For the structural analysis, we used CSi SAP2000 computer software to create numerical models of the reinforced-concrete frame, modeled as equivalent planar structures of a separated central frame with all necessary loads. The analysis included six models of reinforced-concrete frames, as shown in Figure 1. Models labeled "A" each have an infilled central bay, and models labeled "B" each have infilled external bays; models labeled "1" each have four storeys $(12.75 \mathrm{~m})$, "2" each have 7 storeys $(21.75 \mathrm{~m})$, and "3" each have 10 storeys $(30.75 \mathrm{~m})$.

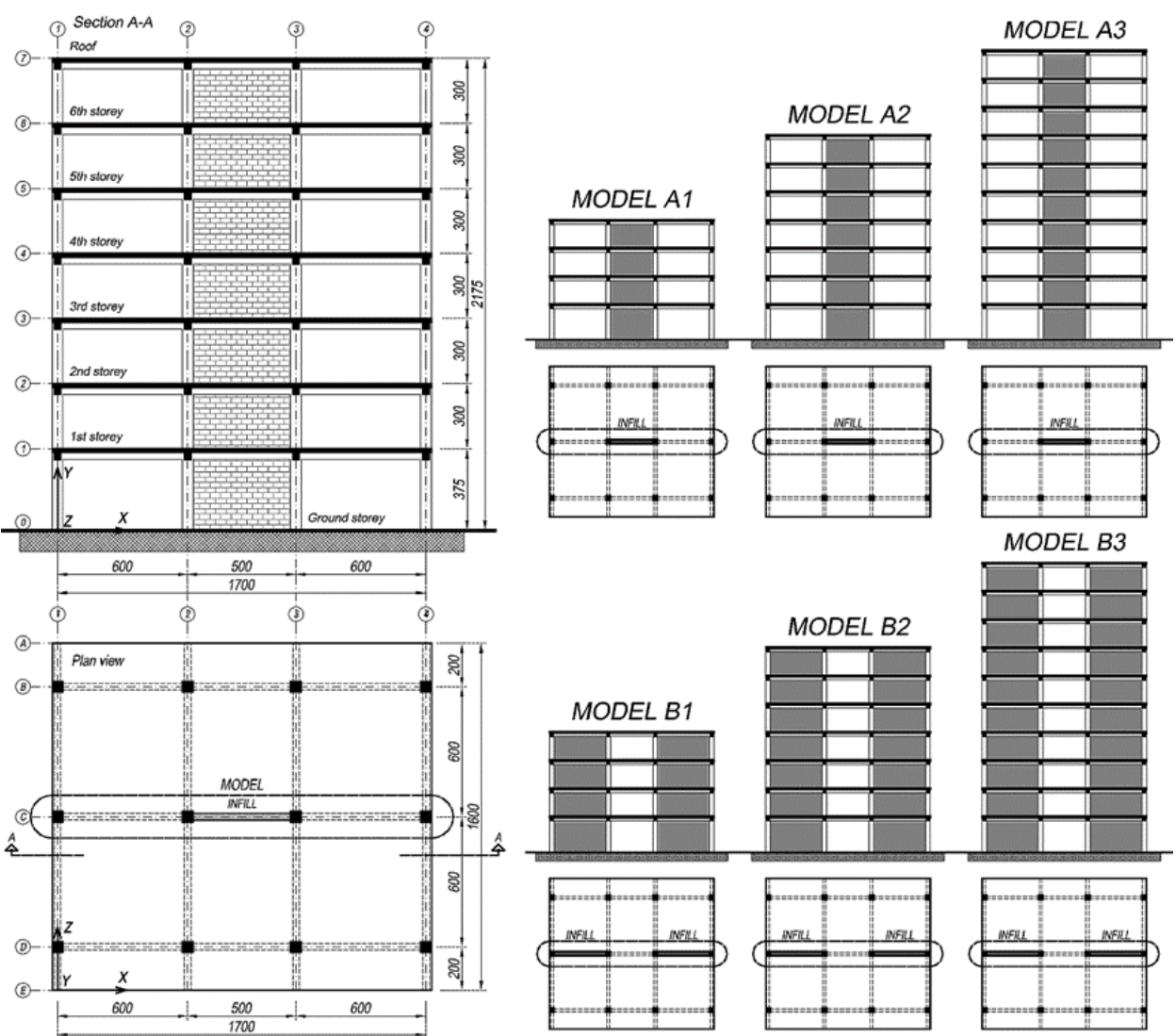

Figure 1 Models of frame structures, showing the different positions of the masonry infill 
All models are designed in accordance with [14] and [15], including the influence of the masonry infill, which we will discuss in more detail later. The structure is located in the IX. seismic zone, a specification for critical areas in Croatia, and has an ambient of moderate humidity (XC3), requires middle class ductility (DCM), and is built on soil category $\mathrm{C}$. The floor area is $280 \mathrm{~m}^{2}$, the roof structure is an impassable roof, the floor structures are reinforced-concrete slabs bearing in two directions that are $18 \mathrm{~cm}$ thick, and the concrete cover for all elements is $3.5 \mathrm{~cm}$ thick. The effective width of each beam, whose dimensions are shown in Figure 2, is determined by the rules of EC8. The materials are C30/37 for the concrete, B500B for the reinforcing steel, and hollow clay bricks in lime mortar for the masonry infill. The modulus of elasticity and shear strength of the masonry infill were selected according to [16], obtained based on experimental results from [17]. The following characteristics were adopted for the masonry infill: thickness $t_{w}=30 \mathrm{~cm}$, characteristic vertical compressive strength $f_{k}=10 \mathrm{MPa}$, specific weight $\gamma_{0}=9 \mathrm{kN} / \mathrm{m}^{3}$, vertical modulus of elasticity $E_{w}=3900 \mathrm{MPa}$, and diagonal shear strength $\tau_{\mathrm{w}}=0.575 \mathrm{MPa}$.

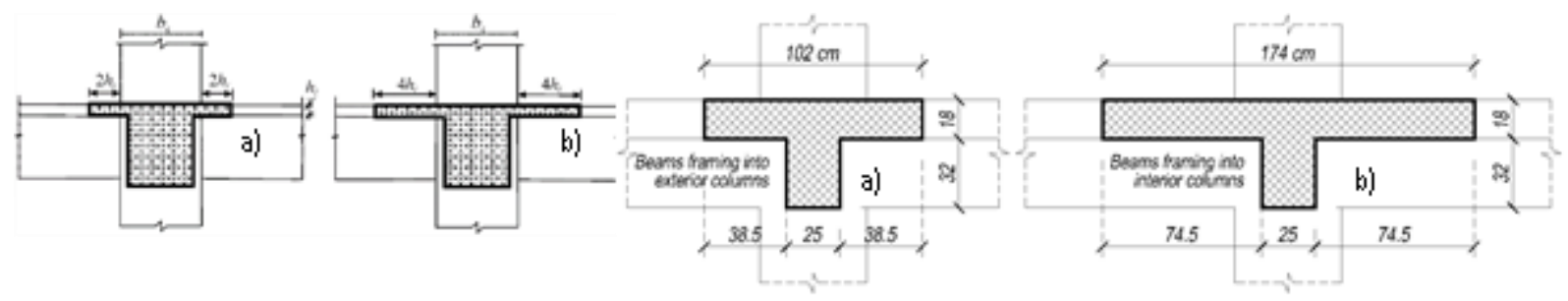

Figure 2 Effective width of the beams according to EC8 for a) beams framing exterior columns and $b$ ) beams framing interior columns

The calculation accounts for the permanent load (dead load of the structure, floor layers, and partition walls), variable load, snow load, and earthquake load. To simplify the calculation, all other loads on the structure (e.g., wind) are ignored. The dead load includes the self-weight of all constructive elements (columns, beams, and slabs), floor layers, balcony layers, and the roof and partition walls. The dead load from the partition walls is set to be $1.5 \mathrm{kN} / \mathrm{m}^{2}$. The self-weight of the frame structure is generated automatically by the computer program. The dead load per floor is $5.6 \mathrm{kN} / \mathrm{m}^{2}$, and that of the flat roof is $8.2 \mathrm{kN} / \mathrm{m}^{2}$. The load from the masonry infill is defined as a line load according the floor plan of the structure. Considering the purpose of the structure according to [18], the load from the infill is defined as a variable load of $3.0 \mathrm{kN} / \mathrm{m}^{2}$. Based ona snow load map of Croatia, the structure is located in the $\mathrm{I}$. zone at an altitude of $94 \mathrm{~m}$, so the snow load on the roof is $0.9 \mathrm{kN} / \mathrm{m}^{2}$.

\section{NUMERICAL MODELS AND ANALYSIS}

\subsection{Lateral force analysis method}

The lateral force analysis method is defined according to EC8. This method can be applied if the fundamental oscillation period of a building is either less than $4 \cdot T_{c}$ or less than $2 \mathrm{~s}$, and if it meets the criteria for regularity in elevation. Linear static analysis was performed on all six models. Structural analysis was performed using the parameters of soil type $C$, spectrum type 1 (surface magnitude $M_{s}$ of the expected earthquake is greater than 5.5), and constant viscous damping of $5 \%$. The horizontal acceleration of the foundation soil is $0.3 \mathrm{~g}$ because the building is located in the IX. seismic zone. Because the building has multiple storeys and bays, the base value of the behavior factor this system, which is defined as medium ductility (DCM), is $q=3.9$.

Note that the behavior factor of 3.9 was adopted as if the building had a pure bare frame (without infill walls), but that factor, to observe the real, nonlinear behavior, should be less than 3.9. However, existing regulations do not provide clear guidance on how to account for the reduced behavior factor caused by the infilled frames. Another approach (not covered here) is, during the design process, not actually modeling the physical behavior of masonry infills, but rather designing a pure bare frame (with infill mass) and limiting the inter-storey drifts in order to control the damage to the masonry infill walls. This problem requires further discussion, and the true behavior factor can be determined more accurately either by experiments or by extensively calibrating nonlinear models based on previous experiments. 
The fundamental oscillation period of vibration $T_{1}$ was determined according to $\mathrm{EC} 8$, as shown in Equation 1. This equation applies to buildings with a total height not exceeding $40 \mathrm{~m}$, for which the dominant parameter is the height of the building. Table 2 shows these results. $\lambda_{T}$ is the correction factor, which equals 0.85 if $T_{1} \leq 2 \cdot T_{C}[s]$, where $T_{c}$ is the upper limit of the period of the constant spectral acceleration branch on the horizontal elastic response spectrum, according to EC8.

$T_{1}=C_{t} \cdot H^{\frac{3}{4}}$

were $C_{t}$ is 0.075 for moment-resistant space concrete frames and $H$ is the height of the building $[\mathrm{m}]$.

Table 2 The fundamental periods of oscillation of model based on EC8

\begin{tabular}{llll}
\hline MODEL & $\boldsymbol{T}_{\mathbf{1}}[\mathbf{s}]$ & $\mathbf{2} \cdot \boldsymbol{T}_{\mathbf{C}}[\mathbf{s}]$ & $\lambda_{\boldsymbol{T}}$ \\
\hline A1 / B1 & 0.506 & 1.2 & 0.85 \\
A2 / B2 & 0.755 & 1.2 & 0.85 \\
A3 / B3 & 0.979 & 1.2 & 0.85 \\
\hline
\end{tabular}

The total mass (including infill walls) of the building during seismic action was determined according to [19], assuming that dead loads are combined with variable loads. Once the fundamental period of oscillation and the mass of the frame are defined, the seismic base shear force can be determined according to EC 8 . Table 3 shows these results.

Table 3 Total mass and fundamental periods of oscillation of the models, determined according to EC8

\begin{tabular}{llll}
\hline MODEL & $\boldsymbol{m}[\mathrm{t}]$ & $\boldsymbol{S}_{d}\left(\boldsymbol{T}_{1}\right)\left[\mathrm{m} / \mathbf{s}^{2}\right]$ & $\boldsymbol{F}_{b}[\mathrm{kN}]$ \\
\hline A1 & 447.1 & 2.17 & 824.6 \\
A2 & 771.6 & 1.72 & 1128.1 \\
A3 & 1096.1 & 1.33 & 1239.1 \\
\hline B1 & 471.2 & 2.17 & 869.1 \\
B2 & 813.5 & 1.72 & 1189.4 \\
B3 & 1155.9 & 1.33 & 1306.7 \\
\hline
\end{tabular}

Because of the models' regularity and their type of construction, the effects of seismic action were determined by applying horizontal forces $F_{\mathrm{i}}$ to all storeys, according to EC8. Table 4 shows the distribution of seismic forces by floor for all models.

Table 4 Linear distribution of lateral seismic forces by storey

\begin{tabular}{llllllll}
\hline Floor & \multirow{2}{*}[\mathrm{m}]{} & $\begin{array}{l}F_{i}[\mathrm{kN}] \\
\text { MODEL A1 }\end{array}$ & MODEL A2 & MODEL A3 & MODEL B1 & MODEL B2 & MODEL B3 \\
\hline 10 & 30.75 & - & - & 233.3 & - & - & 240.3 \\
9 & 27.75 & - & - & 196.9 & - & - & 208.8 \\
8 & 24.75 & - & - & 175.6 & - & - & 186.2 \\
7 & 21.75 & - & 289.1 & 154.3 & - & 298.3 & 163.6 \\
6 & 18.75 & - & 233.1 & 133.1 & - & 247.5 & 141.1 \\
5 & 15.75 & - & 195.8 & 111.8 & - & 207.9 & 118.5 \\
4 & 12.75 & 331.8 & 158.5 & 90.5 & 343.7 & 168.3 & 95.9 \\
3 & 9.75 & 237.3 & 121.2 & 69.2 & 253.0 & 128.7 & 73.4 \\
2 & 6.75 & 164.3 & 83.9 & 47.9 & 175.1 & 89.1 & 50.8 \\
1 & 3.75 & 91.3 & 46.6 & 26.6 & 97.3 & 49.5 & 28.2 \\
Ground & 0 & 0.0 & 0.0 & 0.0 & 0.0 & 0.0 & 0.0 \\
\hline Total & & $\mathbf{8 2 4 . 6}$ & $\mathbf{1 1 2 8 . 1}$ & $\mathbf{1 2 3 9 . 1}$ & $\mathbf{8 6 9 . 1}$ & $\mathbf{1 1 8 9 . 4}$ & $\mathbf{1 3 0 6 . 7}$ \\
\hline
\end{tabular}




\subsection{Modeling infill walls using "shell" element}

At this stage of modeling, the columns are fixed to the foundation, and the infill walls are supported on the ground floor at fixed bearings. The reinforced-concrete frame elements are defined with line elements associated with the corresponding sections. The beams are modeled as T-sections ("Tee frame"), while the columns have regular square cross-sections. To get more precise results, the columns are divided into three finite elements. The stiffness of the floor structures is defined and modeled as a rigid diaphragm, ensuring equal horizontal displacements of beam-column joints. The masonry infill is modeled as a "Shell-thick" element with the appropriate material properties and dimensions. For simplicity, the infill material is assumed to be isotropic, and the properties of the walls are equal in all directions. The wall "shell" element is also divided into finite elements: 10 elements in the $x$-direction and 9 finite elements in the $y$-direction, done so the wall nodes coincide with the column nodes, ensuring valid connections between the columns and the wall element. At this stage of the modeling, contact elements between the wall and frame were not accounted for, although these elements are necessary for modeling the real nonlinear behavior of infill with "shell" elements [20].

The total mass of the structure includes the mass of the structural elements and loads; it is defined with a coefficient of 0.24 for variable loads and 1.0 for dead loads. In our analyses, we design for a combination of gravity and seismic effects. This analysis uses the dead load (which includes the self-weight of partition walls, floor layers, and roof), and the variable load from applied loads and from snow, while only seismic load is defined with equivalent horizontal forces. Table 5 shows the load combinations used with the corresponding coefficients.

\section{Table 5 Load combinations used for the lateral force analysis method}

\begin{tabular}{ll}
\hline LOAD COMBINATIONS & Tags and Coefficients \\
\hline Dead + Variable & $1.35 \cdot G+1.5 \cdot Q$ \\
Dead + Variable + Earthquake & $1.0 \cdot G+1.0 \cdot A_{E d}+\left(0.3 \cdot Q_{\text {storey }}+0.0 \cdot Q_{\text {Roof }}\right)$ \\
\hline
\end{tabular}

Even in the first period of oscillation (Table 6), the position of the infill changes the stiffness of the building. The period for models with infills in the external bays is $32 \%$ lower on average than for models with infill in the central bay. Models A1 and B1 exhibit the largest difference in natural periods-Model B1 has the lower periodand this difference gradually narrows as the number of storeys increases. The decrease in fundamental oscillation period, caused by the masonry infill, reduces the horizontal displacement, and the horizontal roof displacement is higher in models with infill in the central bay than in models with the infill in the external bays. Figure 3 compares the first natural period and horizontal roof displacements of models with "shell" elements. Models A1 and B1 also exhibit the largest difference in displacement, with the period of Model B1 being $55 \%$ lower than that of Model A1. The other sets of models follow the same trend: Models A2 and B2 differ by $53 \%$, and Models A3 and B3 differ by $51 \%$.

Table 6 First three oscillation periods, showing the percentage of activated mass, for models with "shell" elements

\begin{tabular}{|c|c|c|c|c|c|c|}
\hline Mode & $\begin{array}{l}\text { Period } \\
\text { [s] }\end{array}$ & $\begin{array}{l}\text { Activated } \\
\text { mass } \\
\text { proportion } \\
{[\%]}\end{array}$ & $\begin{array}{l}\text { Period } \\
\text { [s] }\end{array}$ & $\begin{array}{l}\text { Activated } \\
\text { mass } \\
\text { proportion } \\
{[\%]}\end{array}$ & $\begin{array}{l}\text { Period } \\
\text { [s] }\end{array}$ & $\begin{array}{l}\text { Activated } \\
\text { mass } \\
\text { proportion } \\
{[\%]}\end{array}$ \\
\hline & Model A1 & & Model A2 & & Model A3 & \\
\hline 1 & 0.266 & 81.63 & 0.524 & 75.35 & 0.832 & 72.77 \\
\hline 2 & 0.084 & 14.78 & 0.152 & 17.89 & 0.231 & 18.10 \\
\hline \multirow[t]{2}{*}{3} & 0.058 & 0.00 & 0.094 & 0.00 & 0.129 & 0.00 \\
\hline & Model B1 & & Model B2 & & Model B3 & \\
\hline 1 & 0.178 & 80.93 & 0.357 & 74.37 & 0.587 & 71.44 \\
\hline 2 & 0.059 & 13.92 & 0.105 & 18.66 & 0.163 & 19.33 \\
\hline 3 & 0.053 & 0.00 & 0.085 & 0.00 & 0.121 & 0.00 \\
\hline
\end{tabular}



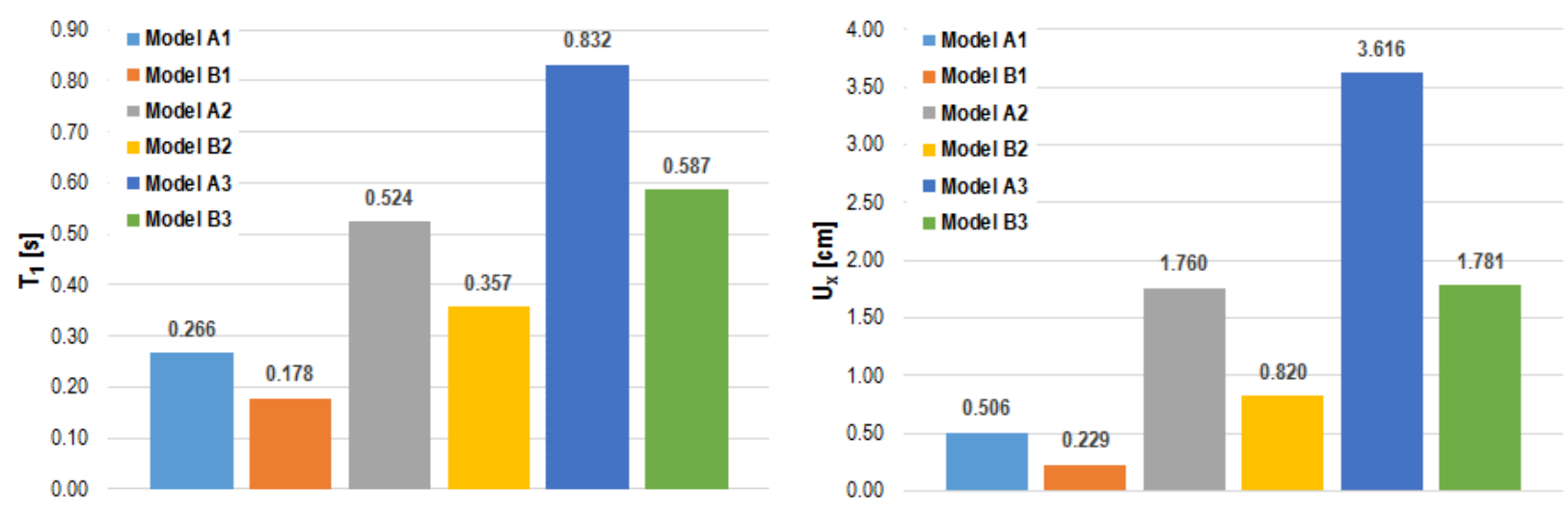

Figure 3 First oscillation period and horizontal roof displacement ofmodels with "shell" elements

Table 7 shows the maximum reactions and displacements, obtained from the combination of seismic loads. The infill caused increased reactions in the surrounding columns because the infill influenced the resistance under seismic loading. The columns reacted more strongly in the direction of the earthquake and in buildings with more storeys and more infill walls.

Table 7 Reactions to seismic combination for models with "shell" elements

\begin{tabular}{llll}
\hline INNER COLUMN & $\boldsymbol{F}_{\mathrm{X}}[\mathrm{kN}]$ & $\boldsymbol{F}_{\mathbf{Z}}[\mathrm{kN}]$ & $\boldsymbol{M}_{\mathrm{Y}}[\mathrm{kNm}]$ \\
\hline Model A1 & 824.6 & 4483.7 & 359.0 \\
Model A2 & 1128.1 & 8179.9 & 522.3 \\
Model A3 & 1239.1 & 11158.1 & 596.1 \\
\hline Model B1 & 869.1 & 4682.2 & 213.1 \\
Model B2 & 1189.37 & 8087.01 & 312.753 \\
Model B3 & 1306.72 & 11491.81 & 360.902 \\
\hline
\end{tabular}

Figure 4 shows diagrams of the total displacement and maximum inter-storey drifts, which also demonstrate the influence of the infill. Not all models exhibit the maximum inter-storey drift on the same storey; however, in all models it appears about halfway up the building's height. All these drifts are produced by seismic combination, whose values are very small because the structures are fairly stiff. A realistic behavior would be achieved by incorporating an orthotropic material because the masonry has lower compressive strength and modulus of elasticity in the horizontal direction; that is, in the direction parallel to the horizontal mortar joints. According to EC8, the design requirement for the moments of the columns and beam capacity is satisfied at each joint in the model both between the primary or secondary seismic beams and between the primary seismic columns, also known as capacity design.

The structural members were designed based on the relevant seismic load combinations according to EC2. UsingCSi SAP2000 software, we obtained the required amount of longitudinal and transverse reinforcement. Note that in some columns this obtained a minimum cross-sectional area of reinforcement of $25 \mathrm{~cm}^{2}$ (i.e., $1 \%$ of the column's gross cross-section, according to EC8), but Table 8 shows only the most loaded column (with the most reinforcement). For the inner columns of Model A3, we chose a reinforcement equal to $2.36 \%$ of the crosssectional area, while for those of all other models, we chose $1.51 \%$ of the cross-sectional area. The external columns are reinforced with $1.51 \%$ of the cross-sectional area. 

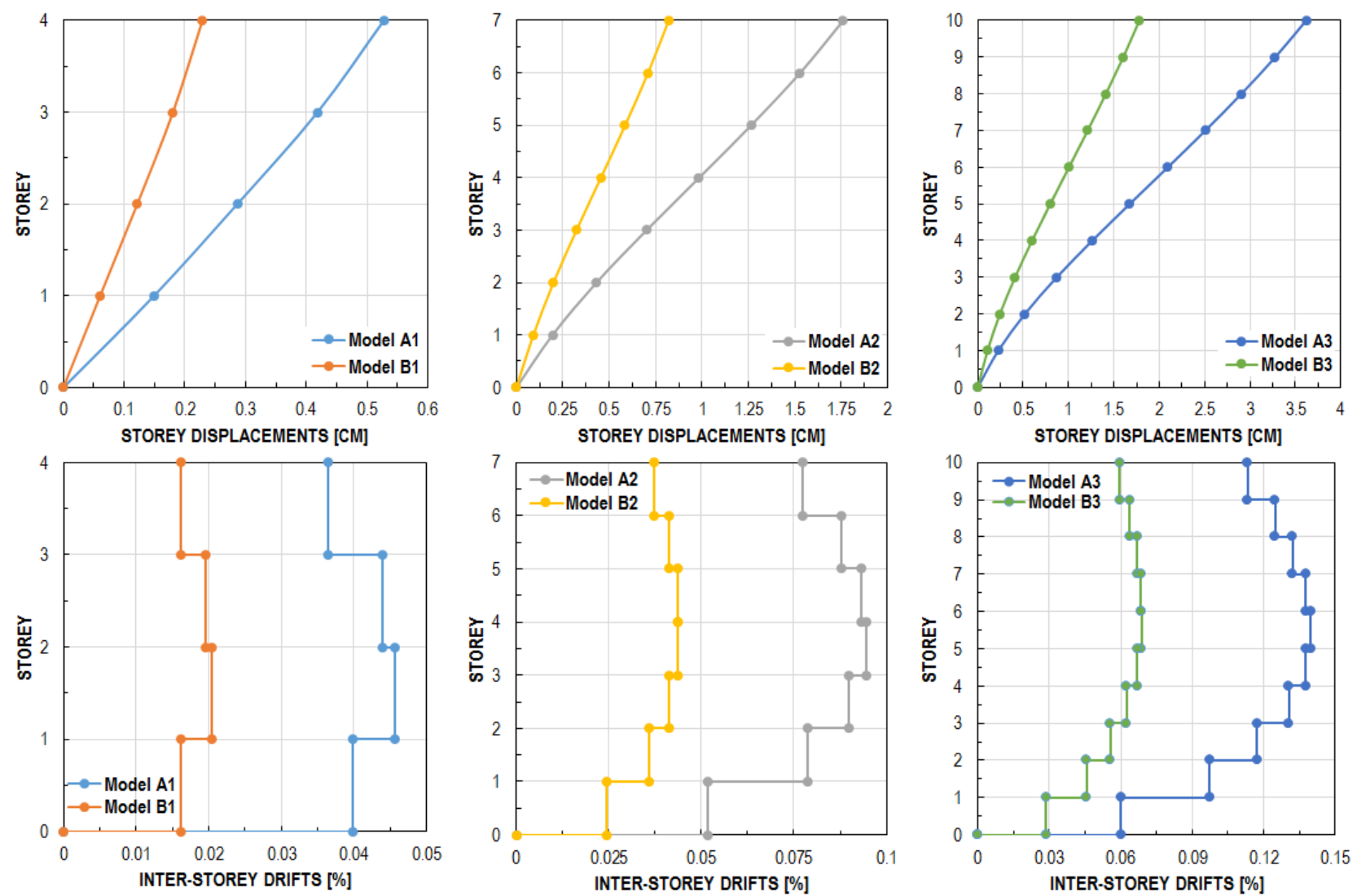

Figure 4 Total displacement and inter-storey drift for seismic load combinations in models with "shell" elements

Table 8 Required and adopted longitudinal reinforcement for interior columns and for the inner and outer beams, where the analysis showed the greatest demand for reinforcement, in Model A3

MODEL A3

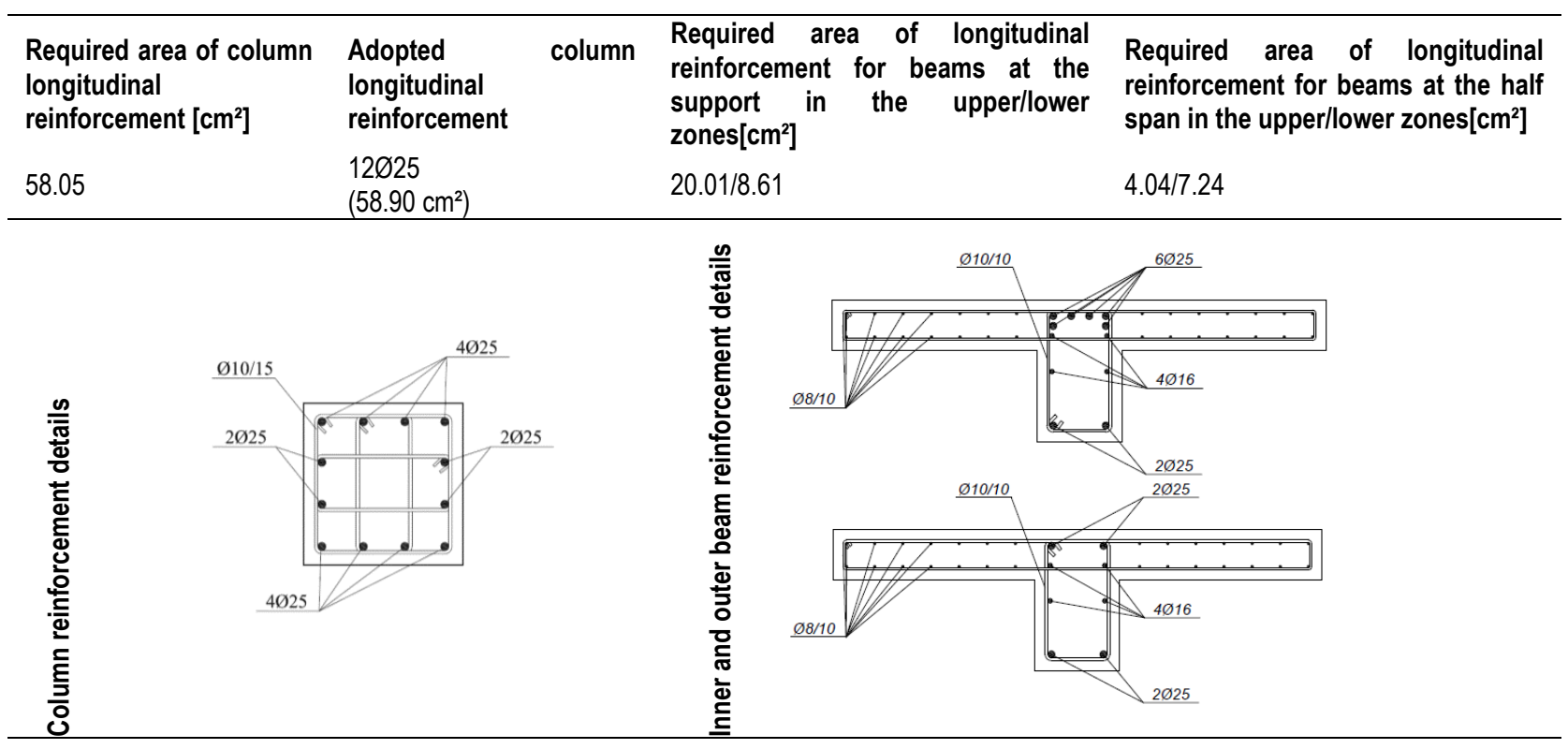




\subsection{Modeling infill walls using linear compressive "gap" elements}

All choices and parameters of the linear analysis and modeling in section 3.2 apply in this model. Here, the masonry infill is modeled using a compressive strut element with an equivalent diagonal strut connecting the opposite joint of the frame. Thus, one wall element is modeled as one compressive strut in the direction of the horizontal load. The diagonals are defined using a "gap" link element, and the geometrical and mechanical characteristics are determined according to the simplified procedure by Panagiotakos et al. [21]. Table 9 shows details of the characteristics of the linear compressive diagonals. Basically, this element is defined as the equivalent secant stiffness of the original envelope capacity curve for the infill walls, which depends on the geometry of the model. The secant stiffness of the infill walls is defined by a linear relationship that passes through a maximum value of force, which is calculated and defined by the capacity envelope shown in Figures 8 and 10. CSi SAP2000 could not simulate the "gap" link element as a pure compressive element in the linear spectral analysis, so we used a simplified lateral force method.

Table 9 Parameters important to describing the capacity envelopes of the masonry infills

\begin{tabular}{|c|c|c|c|c|c|}
\hline \multicolumn{2}{|c|}{ Parameter } & \multirow{2}{*}{$\begin{array}{l}\begin{array}{l}\text { Ground Storey } \\
\text { "l" }\end{array} \\
5.0 \times 3.75 \mathrm{~m}\end{array}$} & \multirow{2}{*}{$\begin{array}{l}\begin{array}{l}\text { Ground Storey } \\
\text { "Ill" }\end{array} \\
6.0 \times 3.75 \mathrm{~m}\end{array}$} & \multirow{2}{*}{$\begin{array}{l}\begin{array}{l}n^{\text {th }} \text { Storey } \\
\text { "l" }\end{array} \\
5.0 \times 3.0 \mathrm{~m}\end{array}$} & \multirow{2}{*}{$\begin{array}{l}n^{\text {th Storey }} \\
\text { "Ill" } \\
6.0 \times 3.0 \mathrm{~m}\end{array}$} \\
\hline Sym. & Unit & & & & \\
\hline$E_{w}$ & {$[\mathrm{MPa}]$} & 3900 & & & \\
\hline$G_{w}$ & {$[\mathrm{MPa}]$} & 1560 & & & \\
\hline$t_{w}$ & {$[\mathrm{~mm}]$} & 300 & & & \\
\hline$d_{w}$ & {$[\mathrm{~mm}]$} & 5550.91 & 6388.47 & 5147.82 & 6041.52 \\
\hline$\theta$ & {$\left[{ }^{\circ}\right]$} & 35.84 & 30.58 & 29.06 & 24.44 \\
\hline$\lambda$ & {$[1 / \mathrm{mm}]$} & 0.0008 & 0.0008 & 0.0009 & 0.0009 \\
\hline$\lambda \cdot h_{w}$ & {$[-]$} & 2.6 & 2.6 & 2.25 & 2.25 \\
\hline$b_{w}$ & [mm] & 648.14 & 751.96 & 657.59 & 781.04 \\
\hline
\end{tabular}

Table 10 First three oscillation periods with the percentage of mass activated in models with linear "gap"

\begin{tabular}{|c|c|c|c|c|c|c|}
\hline \multicolumn{7}{|c|}{ elements } \\
\hline Mode & $\begin{array}{l}\text { Period } \\
\text { [s] }\end{array}$ & $\begin{array}{l}\text { Activated } \\
\text { mass } \\
\text { proportion } \\
{[\%]}\end{array}$ & $\begin{array}{l}\text { Period } \\
\text { [s] }\end{array}$ & $\begin{array}{l}\text { Activated } \\
\text { mass } \\
\text { proportion } \\
{[\%]}\end{array}$ & $\begin{array}{l}\text { Period } \\
\text { [s] }\end{array}$ & $\begin{array}{l}\text { Activated } \\
\text { mass } \\
\text { proportion } \\
{[\%]}\end{array}$ \\
\hline & Model A1 & & Model A2 & & Model A & \\
\hline 1 & 0.4625 & 87.72 & 0.7960 & 83.77 & 1.1546 & 81.43 \\
\hline 2 & 0.1490 & 9.19 & 0.2596 & 10.84 & 0.3753 & 11.81 \\
\hline 3 & 0.0842 & 2.15 & 0.1464 & 3.00 & 0.2100 & 3.34 \\
\hline & Model B1 & & Model B2 & & Model B & \\
\hline 1 & 0.3661 & 88.34 & 0.6311 & 84.01 & 0.9226 & 81.20 \\
\hline 2 & 0.1210 & 8.87 & 0.2082 & 10.97 & 0.3011 & 12.36 \\
\hline 3 & 0.0708 & 1.91 & 0.1187 & 2.85 & 0.1682 & 3.28 \\
\hline
\end{tabular}
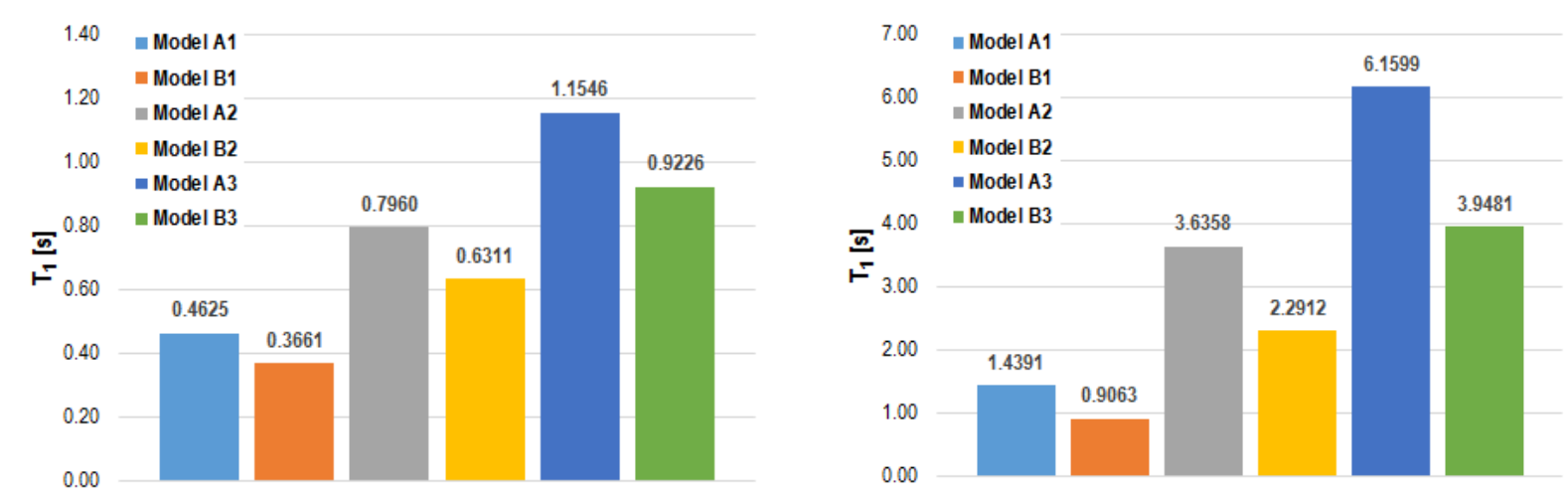

Figure 5 First oscillation period and horizontal roof displacement in models with linear "gap" elements 
As in the model with "shell" elements, the decrease in oscillation period here depends on the type of masonry infill: the first natural period (Table 10) of the "B" models was $21 \%$ lower on average than those of the "A" models.

Table 11 Reactions to seismic combination of models with linear "gap" elements

\begin{tabular}{llll}
\hline INNER COLUMN & $F_{\mathrm{x}}[\mathrm{kN}]$ & $F_{\mathrm{Z}}[\mathrm{kN}]$ & $M_{\mathrm{Y}}[\mathrm{kNm}]$ \\
\hline Model A1 & 824.6 & 4378.2 & 1030.6 \\
Model A2 & 1128.1 & 7592.4 & 1410.7 \\
Model A3 & 1239.1 & 10806.7 & 1542.3 \\
\hline Model B1 & 869.1 & 4520.1 & 678.0 \\
Model B2 & 1189.4 & 7876.4 & 920.4 \\
Model B3 & 1306.7 & 11232.6 & 995.8 \\
\hline
\end{tabular}
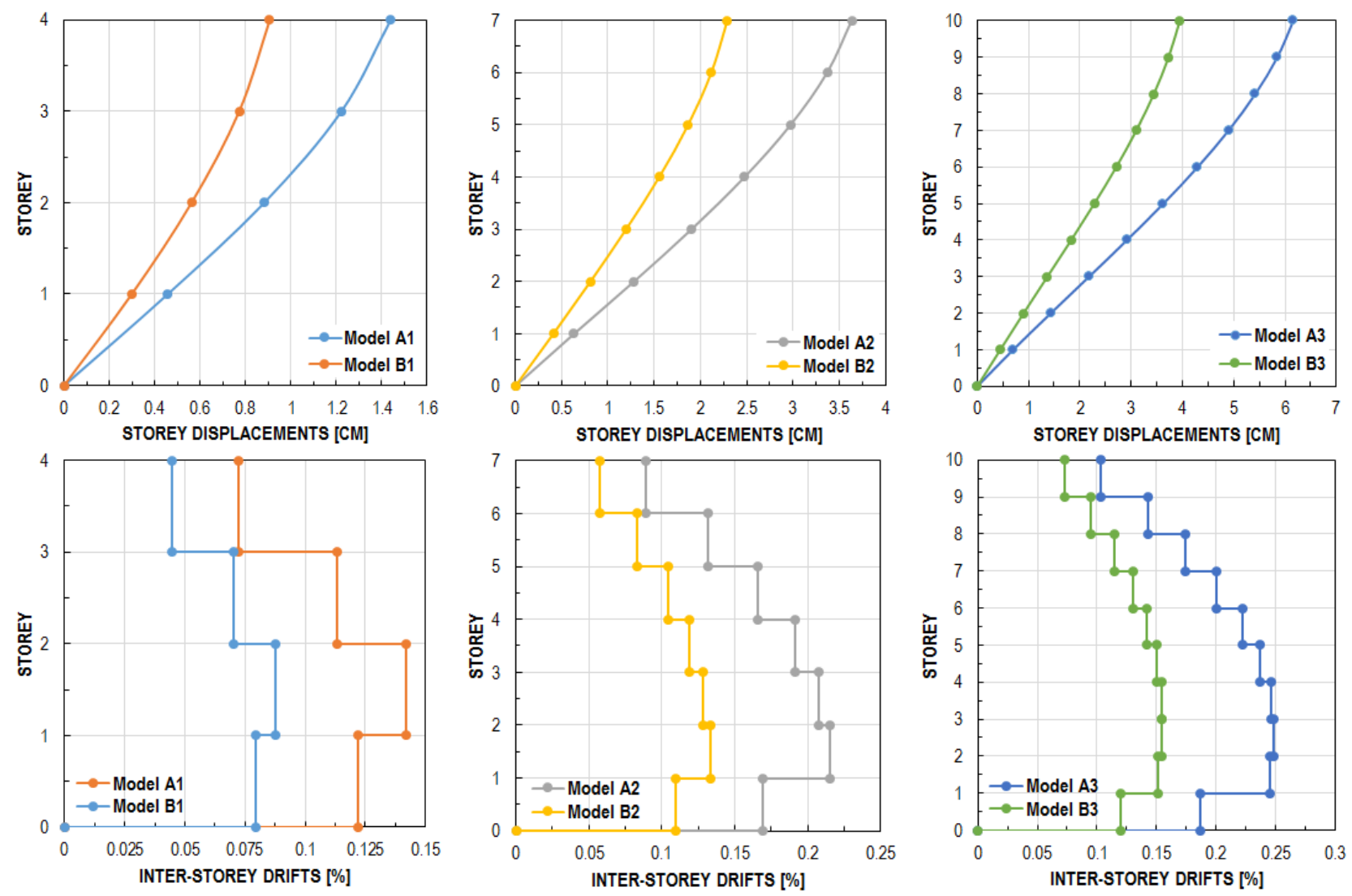

Figure 6 Total displacement and inter-storey drift for seismic load combinations in models with linear "gap" elements

The maximum IDR (Figure 6) appeared between the first and second storeys for models with 4 and 7 storeys, and between the second and third storeys for models with 10 storeys. Table 11 shows the maximum reactions produced by the seismic load combinations. As in the previous analysis, the reactions are higher in models with infill in the external bays than in the model with free columns and infill in the central bay.

All joints also satisfy the condition of strong columns and weak beams (capacity design). We designed the structural elements according to seismic combinations (EC2), as in the previous analysis. Compared to the model with "shell" elements, this model with "gap" link elements produces a greater required reinforcement area for models A2, A3, and B3 (Table 12). 
Table 12 Required and adopted longitudinal reinforcement for interior columns and for the inner and outer beams, where the analysis showed the greatest demand for reinforcement, in Model A3

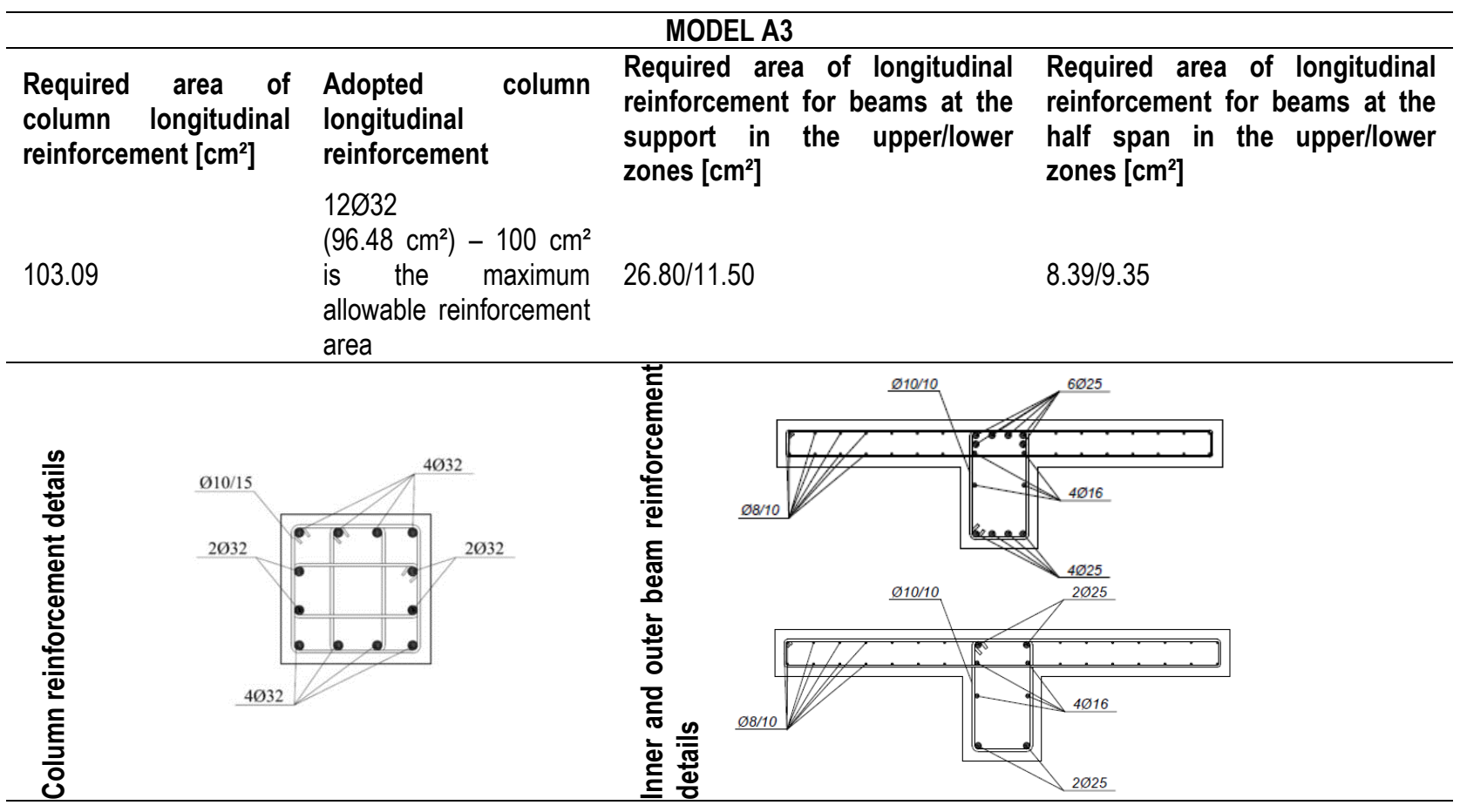

\subsection{Nonlinear dynamic "time-history" analysis}

This analysis uses Models A2 and B2, which represent the original seven-storey prototype building. We selected seven real ground motion records for the nonlinear dynamic analysis. These records are compatible with EC8 for a peak acceleration of $0.3 \mathrm{~g}$, soil category $\mathrm{C}$, and spectrumtype 1 . We took this set of ground motion records from the European Strong-Motion Database (ISESD) [22], which includes earthquakes from the Mediterranean and Europe. Using REXEL 3.5 software [23], we chose a set of records that offers a combination of the desired seven ground motions records per set with the lowest possible average deviation from the target spectrum (Figure 7). The margin of tolerance is $90-130 \%$ of the target spectrum in the range of periods from $0.15 \cdot T_{1}$ and $2 \cdot T_{1}$, where $T_{1}$ is the fundamental period of the building. Table 13 shows data on the selected set of seismic ground motions. The ground motion records are not scaled and were recorded on soil type C, classified according to EC8.

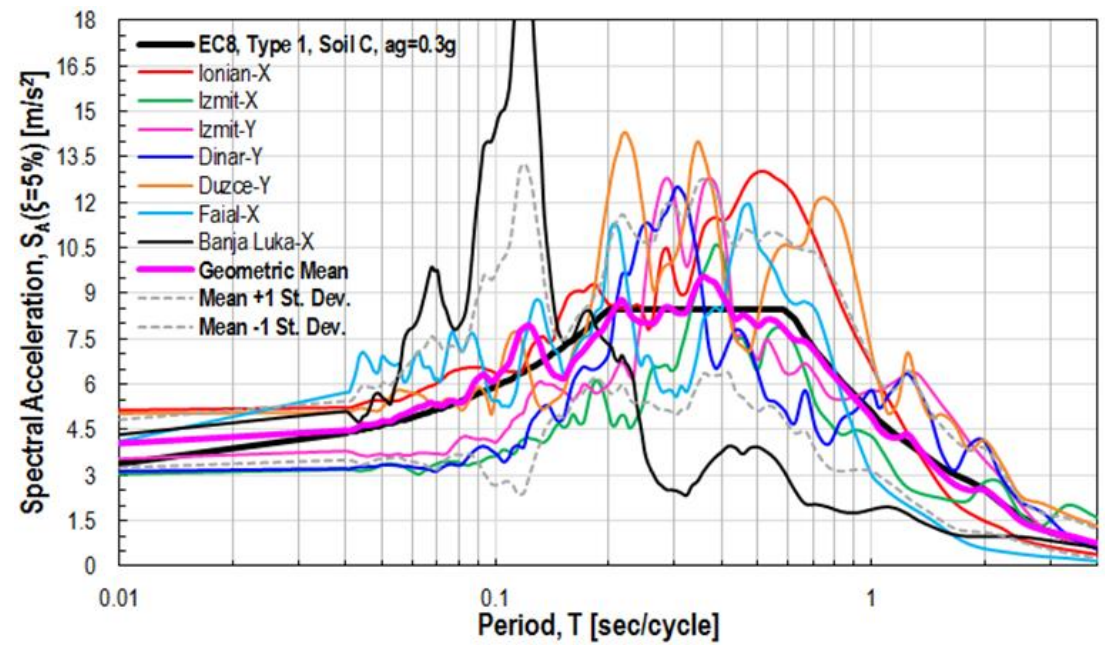

Figure 7 Response spectrum with $5 \%$ damping for seven ground motion records, selected based on the target spectrum EC8, spectrum type 1, soil type C, with a peak ground acceleration of $0.3 \mathrm{~g}$ 
Table 13 Selected set of earthquake records compatible with EC8, spectrum type 1, soil type C

\begin{tabular}{|c|c|c|c|c|c|c|c|c|c|c|c|c|}
\hline $\begin{array}{l}\text { Earthquake } \\
\text { name }\end{array}$ & Date & $M_{\mathrm{w}}$ & $\begin{array}{l}\text { Fault } \\
\text { mechanism }\end{array}$ & $\begin{array}{l}\text { Epic. } \\
\text { dist. } \\
\text { [km] }\end{array}$ & $\begin{array}{l}\text { PGA- } \\
X \\
{\left[\mathrm{~m} / \mathrm{s}^{2}\right]}\end{array}$ & $\begin{array}{l}\text { PGA- } \\
Y \\
{\left[\mathrm{~m} / \mathrm{s}^{2}\right]}\end{array}$ & $\begin{array}{l}\text { PGV- } \\
X \\
{[\mathrm{~m} / \mathrm{s}]}\end{array}$ & $\begin{array}{l}\text { PGV- } \\
Y \\
{[\mathrm{~m} / \mathrm{s}]}\end{array}$ & $\begin{array}{l}\text { Duration } \\
\text { [s] }\end{array}$ & $\begin{array}{l}\text { Arias } \\
\text { intensity } \\
\text { [m/sec] }\end{array}$ & $\begin{array}{l}\text { Housner } \\
\text { intensity } \\
{[\mathrm{m}]}\end{array}$ & $\begin{array}{l}\text { Cum. } \\
\text { abs. } \\
\text { velocity } \\
\text { [m/sec] }\end{array}$ \\
\hline Ionian-X & 4.11 .1973 & 5.8 & Thrust & 15 & 5.146 & 2.498 & 0.570 & 0.255 & 26.51 & 1.3580 & 1.678 & 6.365 \\
\hline Izmit-X & 17.8.1999 & 7.6 & Strike Slip & 100 & 3.038 & 3.542 & 0.413 & 0.542 & 27.17 & 1.0284 & 1.503 & 8.130 \\
\hline Dinar-Y & 1.10 .1995 & 6.4 & Normal & 8 & 2.674 & 3.131 & 0.294 & 0.406 & 27.95 & 1.9433 & 2.060 & 13.102 \\
\hline Faial-X & 9.7 .1998 & 6.1 & Strike Slip & 11 & 4.120 & 3.749 & 0.283 & 0.354 & 9.33 & 1.3920 & 0.956 & 6.241 \\
\hline Izmit-Y & 17.8.1999 & 7.6 & Strike Slip & 100 & 3.038 & 3.542 & 0.413 & 0.542 & 27.17 & 1.3080 & 2.226 & 8.022 \\
\hline Duzce-Y & 12.11.1999 & 7.2 & Oblique & 8 & 3.699 & 5.036 & 0.357 & 0.635 & 25.89 & 2.7140 & 2.535 & 13.121 \\
\hline $\begin{array}{l}\text { Banja Luka- } \\
X\end{array}$ & 13.8.1981 & 5.7 & Oblique & 7 & 4.340 & 3.966 & 0.263 & 0.165 & 32.30 & 0.7641 & 0.697 & 4.235 \\
\hline
\end{tabular}

\subsection{Nonlinear model with compressive strut for the masonry infill}

Because we wished to avoid the complexity of nonlinear dynamic analysis, but also wished to robustly predict the global seismic response, we used a macromodel for infill walls in accordance with Panagiotakos et al. [21]. Modeling the masonry infill with one or more nonlinear compressive struts gives satisfactory nonlinear behavior of the materials and elements. The behavior of the masonry infill in nonlinear analysis is described with suitable envelope-capacity curves, also called multi-linear "backbone" curves, and are designed according to the actual hysteretic behavior of infills. The behavior of the diagonals is defined with an envelope of horizontal force and horizontal displacement, as shown in Figure 8.

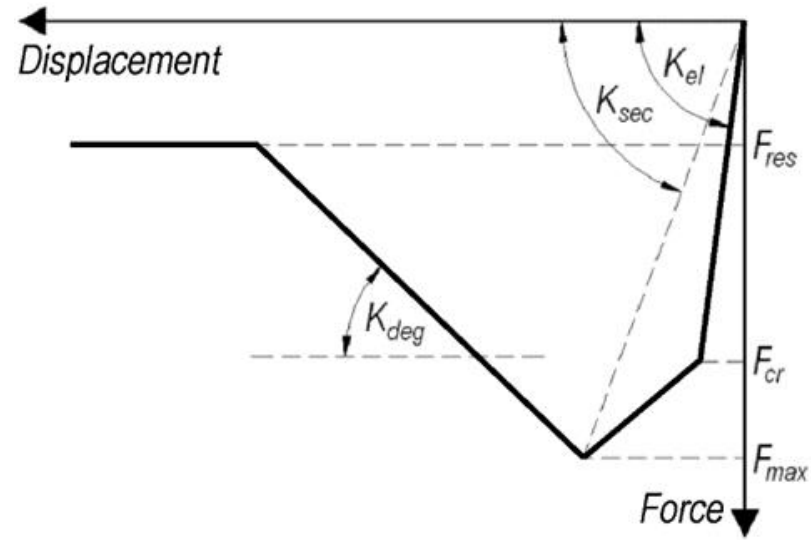

Figure 8 Backbone capacity curve of the masonry infills (in compression), which ascribes certain hysteresis behavior according to [21]

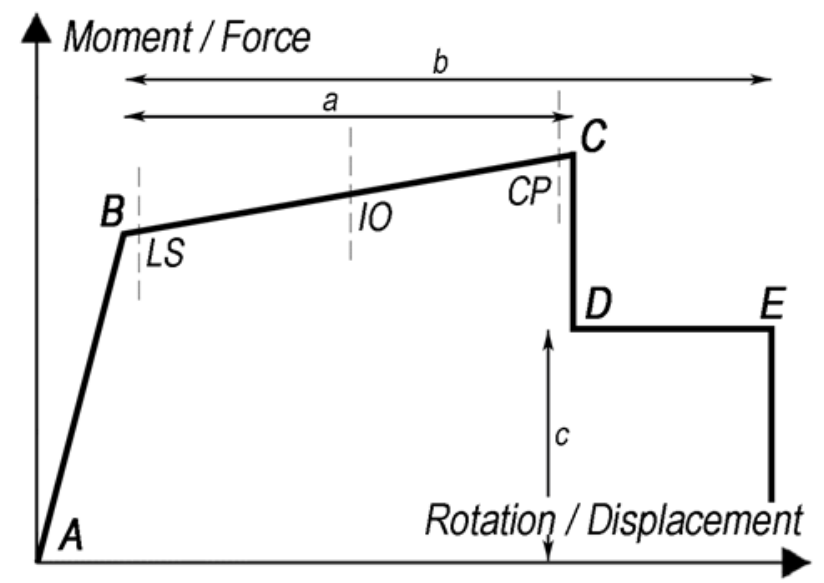

Figure 9 Schematic of the capacity envelopes of columns and beams, defined in [24] 
We calculated the nonlinear characteristics of the compressive diagonal using the following equations. The width of the diagonal is calculated as:

$$
\begin{aligned}
& b_{w}=0.175 \cdot\left(\lambda \cdot h_{c}\right)^{-0.4} \cdot d_{w} \\
& \lambda=\left[\frac{E_{w} \cdot t_{w} \cdot \sin 2 \theta}{4 \cdot E_{c} \cdot I_{c} \cdot h_{w}}\right]^{\frac{1}{4}}
\end{aligned}
$$

where $h_{c}$ is the column height, $d_{w}$ is the length of the compressive diagonal, $E_{w}$ is the modulus of elasticity of the masonry infill, $t_{w}$ is the thickness of the masonry infill, $\theta$ is the angle of inclination of the compressive diagonal, $E_{c}$ is the modulus of elasticity of the concrete material, $I_{c}$ is the column moment of inertia, $h_{w}$ is the height of the masonry infill, and $\lambda$ is a parameter that accounts for the relationship between the stiffness of the masonry infill and frame. The first elastic part of the behavior of the masonry infill envelope is the linear elastic behavior of the restoration at crack onset, where the stiffness is calculated as:

$$
K_{e l}=\frac{G_{w} \cdot A_{w}}{h_{w}}
$$

where $G_{w}$ is the elastic shear modulus of the masonry infill and $A_{w}$ is the cross-sectional area of the masonry infill. The force $F_{c r}$ represents the shear bearing capacity of the masonry infill at crack onset, and it can be determined as the product of the shear strength $T_{c r}$ and cross-sectional area of the masonry infill $A_{w}$ :

$$
F_{c r}=\tau_{c r} \cdot A_{w}
$$

The second part of the capacity envelope extends from crack onset to the maximum capacity of the masonry infill $F_{\text {max }}$, and can be estimated as:

$$
F_{\text {max }}=1.3 \cdot F_{c r}
$$

The coefficient of this equation generally depends on the type of filling, and is 1.30 for a masonry infill made from ceramic blocks. The secant stiffness associated with the load capacity of the wall, or force $F_{c r}$, can be determined as:

$$
K_{\text {sec }}=\frac{E_{w} \cdot b_{w} \cdot t_{w}}{d_{w}} \cdot \cos ^{2} \theta
$$

The third part of the capacity envelope describes the decline in stiffness after reaching the maximum capacity, caused by infill failure. It is defined by the product of the elastic stiffness at crack on set and the parameter $\alpha$ :

$$
K_{\text {deg }}=-\alpha \cdot K_{e l}
$$

We propose that the parameter acan range from 0.005 to 0.1 (we adopted 0.05 ), where higher values correspond to very brittle failure. Last, the horizontal part of the capacity envelope is residual bearing capacity of the masonry infill, which can be estimated as:

$$
F_{\text {res }}=0.3 \cdot F_{\text {max }}
$$

Because these expressions apply in the horizontal direction, they are divided with the cosine of the diagonal inclination to produce the given values, which are valid in the direction of the angled compressive struts. The input data we used to calculate the envelope of the masonry infill are as follows: modulus of elasticity for the masonry infill $E_{W}=3900 \mathrm{MPa}$, shear modulus $G_{w}=1560 \mathrm{MPa}$, shear strength $T_{c r}=0.575 \mathrm{MPa}$, and modulus of elasticity for the concrete material $E_{c}=32,000 \mathrm{MPa}$. Because the geometry (i.e., width and height) of the frame affects the shape of the envelope, we defined four envelopes, two for the groups of "A" and " $B$ " models, and two for the ground floor and other floors. Figure 10 shows the calculated envelopes. 


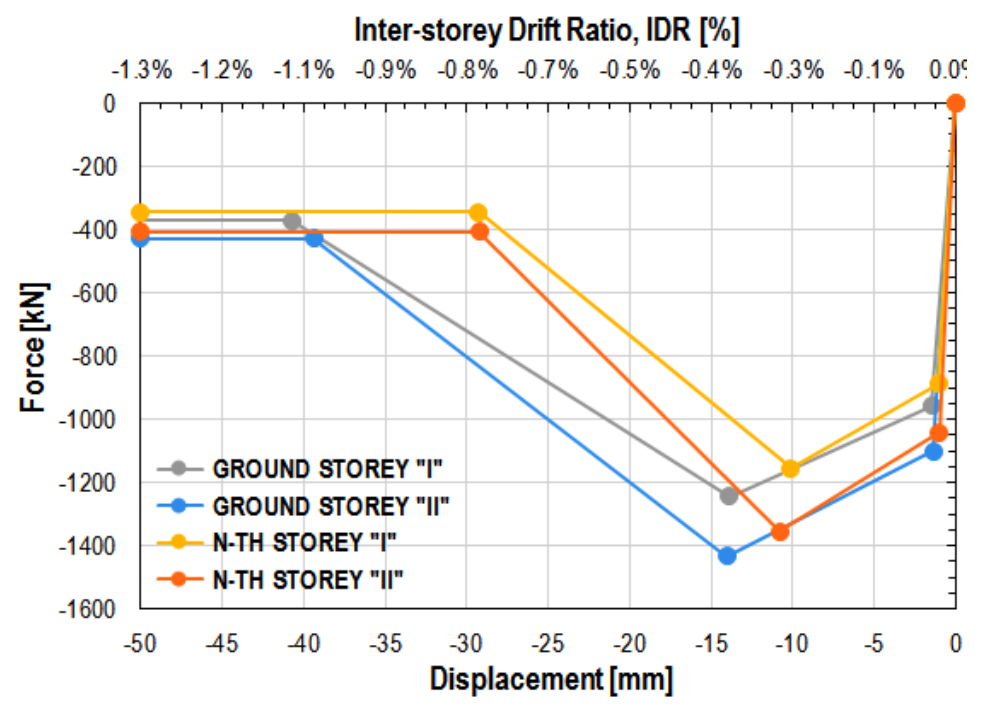

Figure 10 Four capacity envelopes of masonry infills for Models A2 and B2

The beams and columns are modeled as elastic elements with lumped plastic behavior in the areas of the plastic hinges. The lengths of plastic hinges, used to define the concentrated plasticity of the columns and beams, were obtained according to [25]:

$L_{p}=0.08 \cdot L_{s}+0.022 \cdot d_{b} \cdot f_{y}$

where $L_{s}$ is the column height [m], $d_{b}$ is the diameter of the main longitudinal reinforcing bars [m], and $f_{y}$ is the reinforcement steel stress at yielding [MPa]. Table 9 gives the important parameters for describing the capacity envelope of the masonry infills.

The plastic hinge for the columns and beams were modeled automatically with CSi SAP2000, using envelopes defined by FEMA guidelines (Figure 9) [24]. In nonlinear analysis of concrete and masonry, cracking is not accounted for, as is the case in the linear analysis according to EC8. Because the concentrated plasticity for columns and beams is defined automatically according to FEMA 356 guidelines, we can account for the effective stiffness of the section by only reducing the gross cross-section; for example, by $50 \%$, according to EC8 and FEMA 356. Thevalues of plastic rotations for the elements and the analysis procedure are located in Tables 6-7 and 6-8 of the FEMA 356 guidelines [24]. Each element is assigned an individual plastic rotation and corresponding moment, taken directly from the moment-curvature analysis produced by CSi SAP2000.

Such a model with rotational springs only considers failure caused by a bending moment, ignoring the possibility of exceeding the shear or axial capacity. In this model, we included section confinement of transverse reinforcement, in which we obtained a relevant load combination, used to adopt the $P$ and $V$ values, from the previous analysis according to [24]. The reinforcement amount is adopted automatically from the current design. Based on these characteristics, the program defines a moment-rotation envelope, which defines the behavior of the plastic hinge in terms of a rotational spring, as shown in Figure 9. The masonry infill is modeled with two compressive diagonals, using the same approach as in the previous section, by connecting two opposite corners of the frame; this model, however, is defined as a purely nonlinear. The diagonals are defined using "link" elements ("multi-linear plastic"), and we calculated the associated geometrical and mechanical characteristics according to Panagiotakoset al. [21]. To explain the nonlinear hysteretic behavior of the infill, we used rules introduced by Takedaet al. [26]. The dynamic behavior of the model is observed using Rayleigh damping rules, but we adopted a constant damping of $5 \%$ because it is simpler and produced negligible differences. We accounted for the contribution of P-Delta effects (also known as geometric nonlinearity) according to secondorder theory. This condition magnifies storey drift and certain mechanical behaviors while reducing deformation capacity. The P-Delta effect typically involves large external forces upon relatively small displacements.

As in the linear analysis, in the nonlinear analysis the infills increased the stiffness of the system, as shown in the first natural periods. The first period of Model B2 $\left(T_{1}=0.55 \mathrm{~s}\right)$ was $29 \%$ lower than that of Model A2 $\left(T_{1}=0.778 \mathrm{~s}\right)$ (Table 14). 
Table 14 First three natural oscillation periods of Models A2 and B2

\begin{tabular}{lll}
\hline Mode & $\begin{array}{l}\text { Period [s] } \\
\text { Model A2 }\end{array}$ & Model B2 \\
\hline 1 & 0.78 & 0.55 \\
2 & 0.25 & 0.18 \\
3 & 0.14 & 0.10 \\
\hline
\end{tabular}

Table 15 shows the relevant model reactions, obtained from the seismic load combinations averaged over seven seismic responses. As in the linear analysis, in Model A2 the inner columns surrounding the masonry infill exhibited greater reactions because of how the masonry infill redistributed loads. Figure 11 shows the total displacements and inter-storey drifts for Models A2 and B2, and Figure 12 shows the nonlinear hysteresis behavior of the infill model for the ground storey reacting to three earthquakes taken from the records. Figure 13 compares the periods and maximum inter-storey drift ratios from the different modeling approaches.

Table 15 Reactions of Models A2 and B2 for the time-history combination

\begin{tabular}{|c|c|c|c|c|c|c|}
\hline \multirow[b]{2}{*}{ Combination } & \multirow{2}{*}{$\begin{array}{l}\text { Model A2 } \\
\text { FX } \\
{[\mathrm{kN}]}\end{array}$} & \multirow[b]{2}{*}{$\begin{array}{l}\mathrm{FZ} \\
{[\mathrm{kN}]}\end{array}$} & \multirow[b]{2}{*}{$\begin{array}{l}\text { MY } \\
{[\mathrm{kNm}]}\end{array}$} & \multicolumn{2}{|c|}{ Model B2 } & \multirow[b]{2}{*}{$\begin{array}{l}\text { MY } \\
{[\mathrm{kNm}]}\end{array}$} \\
\hline & & & & $\begin{array}{l}\text { FX } \\
{[k N]}\end{array}$ & $\begin{array}{l}\mathrm{FZ} \\
{[\mathrm{kN}]}\end{array}$ & \\
\hline (Ionian-X) & 2893.9 & 17294.5 & 4796.8 & 3585.4 & 23256.1 & 3529.1 \\
\hline (Izmit-X) & 1913.6 & 17510.4 & 1964.7 & 3439.3 & 22262.4 & 2174.8 \\
\hline o (Izmit-Y) & 2591.5 & 17539.8 & 3918.7 & 3432.5 & 25190.7 & 2225.3 \\
\hline$\underset{\mp}{\varpi}$ (Dinar-Y) & 4583.2 & 20211.3 & 9330.4 & 2965.3 & 24512.6 & 1422.7 \\
\hline త్ల (Faial-X) & 1906.9 & 16563.7 & 1982.8 & 3395.0 & 24569.8 & 2016.8 \\
\hline (Duzce-Y) & 4359.1 & 19938.4 & 8887.7 & 5613.0 & 23662.1 & 10509.8 \\
\hline Ð (Banja Luka-X) & 1549.3 & 16088.4 & 1224.2 & 3329.6 & 24396.6 & 1818.7 \\
\hline Mean Value & 2828.2 & 17878.1 & 4586.5 & 3680.0 & 23978.6 & 3385.3 \\
\hline
\end{tabular}



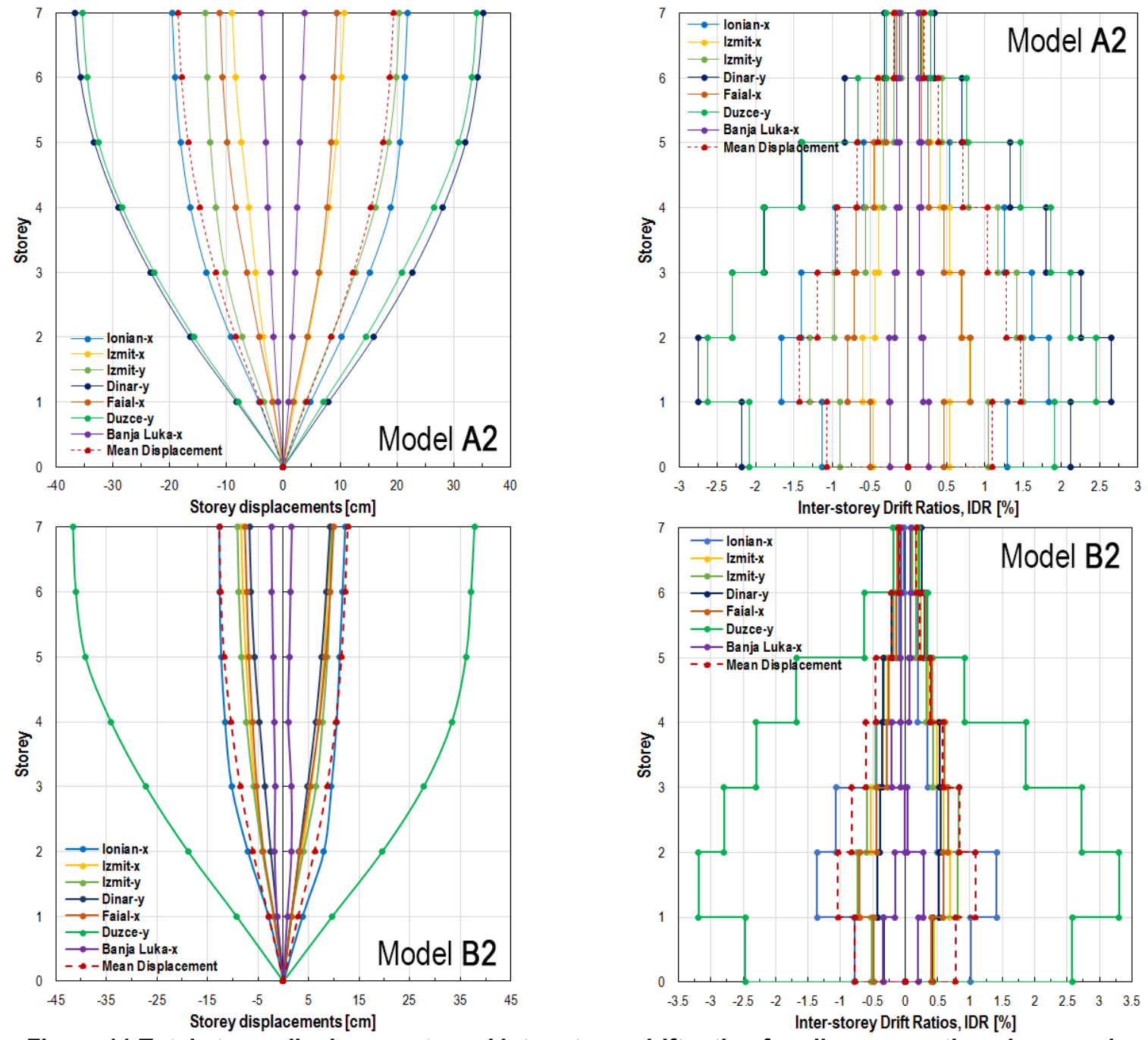

Figure 11 Total storey displacements and inter-storey drift ratios for all seven earthquake records
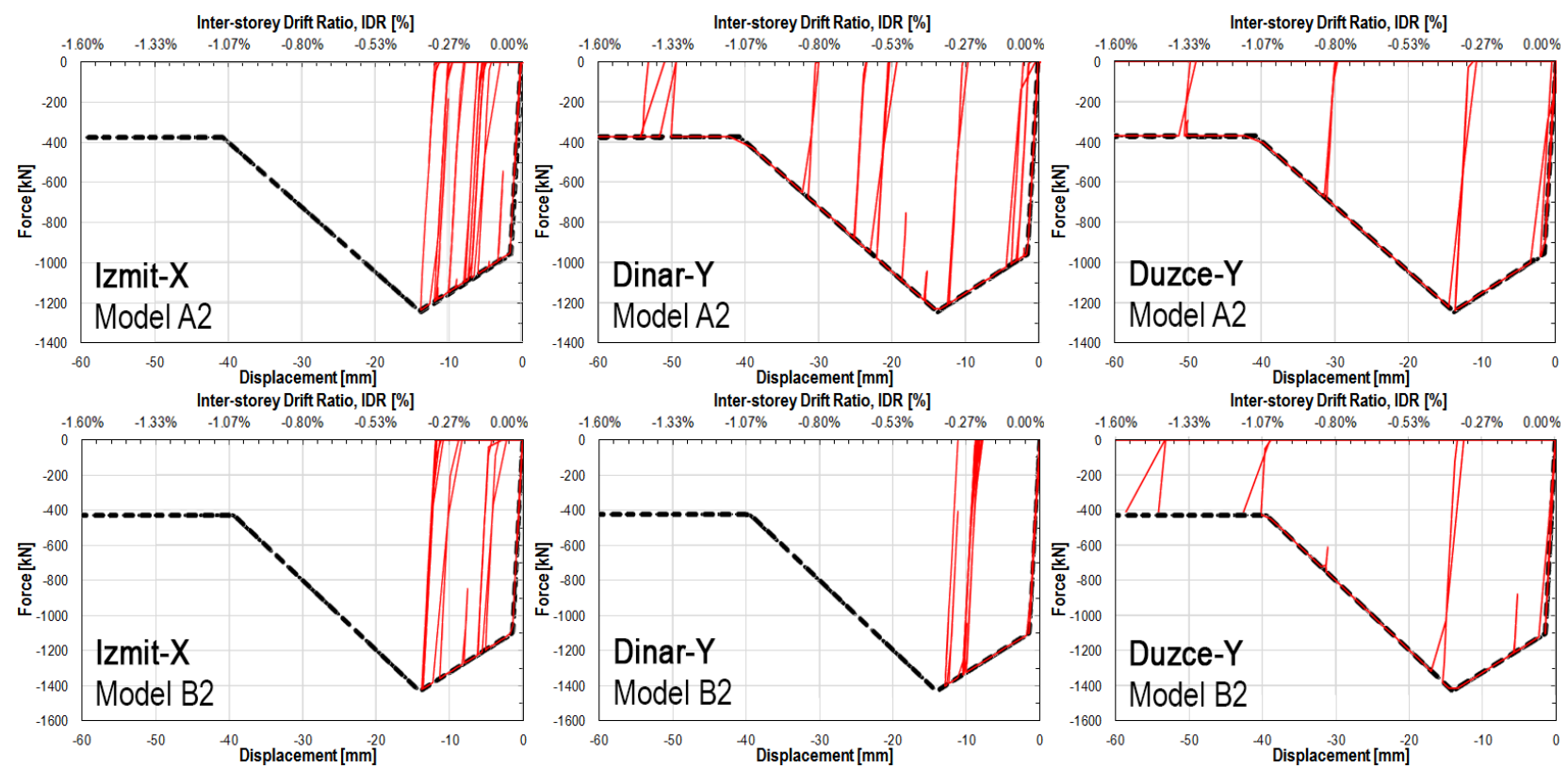

Figure 12 Nonlinear hysteretic behavior of infill on ground storey for three earthquakes 

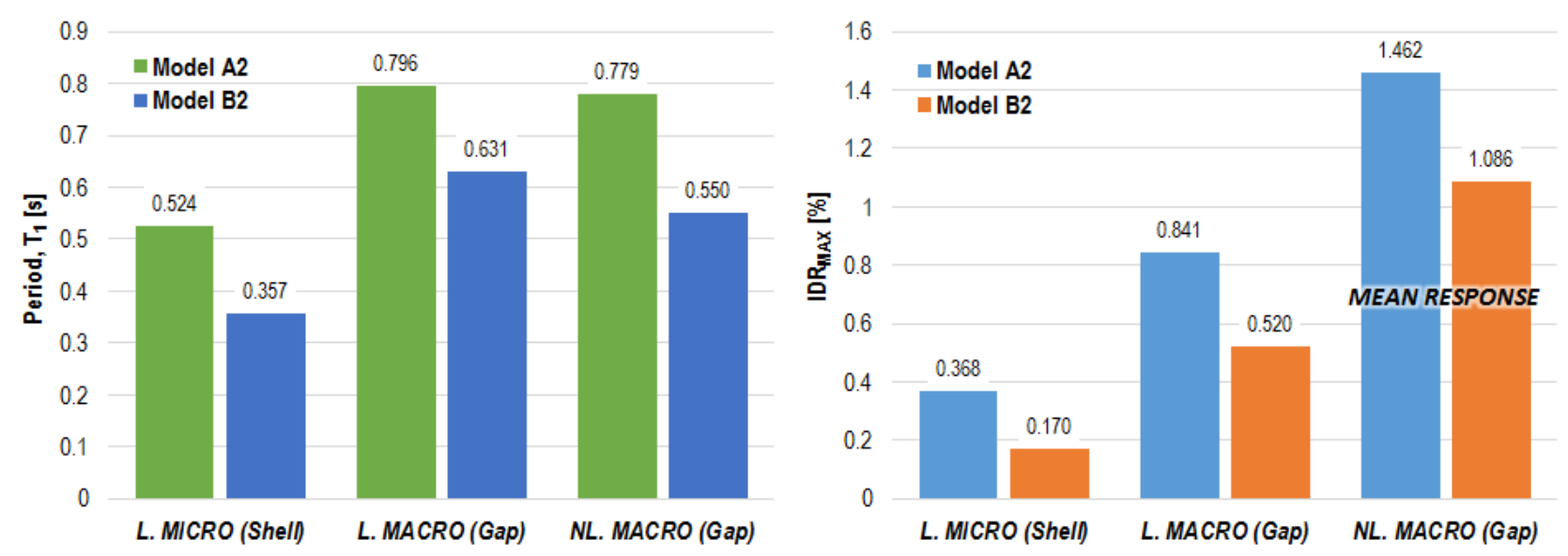

Figure 13 Periods and maximum inter-storey drift ratios given by various modeling approaches

\section{CONCLUSIONS AND REMARKS}

This paper describes and analyzes some simplified models that show how masonry infill walls affect the behavior of reinforced-concrete frames, investigating various modeling approaches and configurations of infill walls. We numerically modeled six buildings, which had different configurations of their masonry infill and different numbers of storeys. We performed linear static analysis on all six models, and performed nonlinear dynamic time-history analysis on two models of a prototype (reference) building with different infill configurations. The frames were set up in accordance with current technical regulations, and were tested with static (vertical) and dynamic (horizontal/earthquake) actions.

The linear micromodel we called the simplified "shell" model, and the linear macromodel we called the "gap" model. For the first period of oscillation, the linear micromodel gave higher stiffness and lower period (differences of up to $40 \%$ ) compared to the other two models, while the linear and nonlinear macromodels gave nearly the same results, within $10 \%$ of each other. We attribute this difference between "shell" and "gap" models to excessive simplifications in the micromodel: the assumption of the material as isotropic rather than orthotropic, and the exclusion of contact elements that transmit only compressive stresses. Including an orthotropic material would certainly make the structure softer-which is closer to the true period and drift behavior-because of the lower horizontal strengths.

These same reasons can used to explain the differences in the maximum inter-story drifts, as shown Figure 13; to compare the linear and nonlinear inter-story drifts, the calculated values for the linear models are multiplied by a behavior factor of 3.9.The linear macromodel (L. Gap) exhibits a maximum inter-storey drift half that of the nonlinear macromodel (NL. Gap), and the linear micromodel (L. Shell) exhibits one four times lower. Although linear models can "catch up" by including the impact of nonlinear behavior in a behavior factor, the drift estimates can remain very different because of the modeling assumptions described before. The average nonlinear response can also vary significantly depending on the set-to-set variability of ground motion records, even for the same hazard level; because of this variability, the mean value must be considered along with a coefficient of variation.

The expected lateral load in the ground motion records for the selected hazard level, as shown in Figure 7 , produced inter-storey drift ratios of $\sim 1.5 \%$ and $\sim 1.1 \%$ for models $\mathrm{A} 2$ and $\mathrm{B} 2$; these ratios are realistic, so these results are likely the most relevant. We must note the variability of the ground motion records: the structural response for Model B2 to one ground motion record (Duzce- $Y$ ) is three times higher than the mean of the structural responses for all seven records.

The macromodel takes advantage of the accuracy of the micromodel, yet it is computationally efficient, making it useful for seismic performance assessments that require repeated nonlinear dynamic analyses. Nonlinear modeling has proven to be more detailed but significantly more complex. The masonry infill can further be modeled as multi-strut model in order to determine the local effects of the frame-infill interaction. There are many models of the concentrated plasticity of columns and beams, but it is good to choose a model that contains 
enough parameters to control the hysteretic behavior while also being able to model the infill wall. Using a model like this, it would be easier to calibrate the response of the structure. Compared to linear models, nonlinear models more realistically describe the behavior of the model, but require more effort in defining the necessary parameters.

Linear models may be sufficient for designing a building, but understanding composite behavior in more depth requires nonlinear models. There are evident obvious differences among the models in the periods, total displacements, and inter-storey drift ratios, as well as in the base shear demand. Thus, we conclude that it is necessary to account for the masonry infill walls, as they significantly change the structural behavior and affect the required reinforcement in columns and beams. Current guidelines must be carefully assessed in order to avoid the possible negatives of masonry infills, of which the most interesting (in planar cases) are the shear failure of columns, failure of beam-column joints, and formation of a short column.

\section{References}

[1] Fiorato, A. E.; Sozen, M. A.; Gamble, W. L. 1970: An Investigation of the Interaction of Reinforced Concrete Frames with Masonry Filler Walls. Technical report, University of Illinois Engineering Experiment Station. College of Engineering. University of Illinois at Urbana-Champaign.

[2] Brokken, S. T.; Bertero, V. V. 1981: Studies on Effects of Infills in Seismic Resistant RC Construction. NASA STI/Recon Technical Report N 82:31576.

[3] Calvi, G. M.; Bolognini, D. 2001: Seismic Response of Reinforced Concrete Frames Infilled with Weakly Reinforced Masonry Panels. Journal of Earthquake Engineering, Volume 5, pp. 153-185.

[4] Negro, P.; Verzeletti, G. 1996: Effect of Infills on the Global Behaviour of RC Frames: Energy Considerations from Pseudodynamic Tests. Earthquake Engineering \& Structural Dynamics, Volume 25, pp. 753-773.

[5] Žarnić, R.; Gostič, S.; Crewe, A. J.; Taylor, C. A. 2001: Shaking Table Tests of 1:4 Reduced-scale Models of Masonry Infilled Reinforced Concrete Frame Buildings. Earthquake Engineering \& Structural Dynamics, Volume 30, pp. 819-834.

[6] Hashemi, A.; Mosalam, K. M. 2006: Shake-table Experiment on Reinforced Concrete Structure Containing Masonry Infill Wall. Earthquake Engineering \& Structural Dynamics, Volume 35, pp. 1827-1852.

[7] Pujol, S.; Fick, D. 2010: The Test of a Full-scale Three-story RC Structure with Masonry Infill Walls. Engineering Structures, Volume 32, pp. 3112-3121.

[8] Fardis, M. N.; Bousias, S. N.; Franchioni, G.; Panagiotakos, T. B. 1999: Seismic Response and Design of RC Structures with Plan-eccentric Masonry Infills. Earthquake Engineering \& Structural Dynamics, Volume 28, pp. 173-191.

[9] Wood, R. H. 1978: Plasticity, Composite Action and Collapse Design of Unreinforced Shear Wall Panels in Frames. In Instn Civ. Engrs. (ICE) Proceedings, Volume 65,Issue 2, pp. 381-411.

[10] Murty, C. V. R.; Jain, S. K. 2000: Beneficial Influence of Masonry Infill Walls on Seismic Performance of RC Frame Buildings. In12th World Conference on Earthquake Engineering (12WCEE), New Zealand, Paper No. 1790.

[11] El-Dakhakhni, W. W. 2002: Experimental and Analytical Seismic Evaluation of Concrete Masonry-Infilled Steel Frames Retrofitted Using GFRP Laminates. Ph.D. Thesis, Drexel University.

[12] Kalman Šipoš, T.; Sigmund, V.; Hadzima-Nyarko, M. 2013: Earthquake Performance of Infilled Frames Using Neural Networks and Experimental Database. Engineering Structures, Volume 51, pp. 113-127.

[13] Wight, J. K.; Nakata., S. 1982:Construction of the Full-scale Seven-story Reinforced Concrete Test Structure, Report Presented during The Second Joint Technical Coordinating Committee, U.S.-Japan Cooperative Earthquake Research Program Utilizing Large-Scale Testing Facilities, Tsukuba, Japan.

[14] EN 1992-1:2004 (2004): Eurocode 2 - Design of Concrete Structures-Part 1: General Rules and Rules for Buildings. European Committee for Standardization, CEN.

[15] EN 1998-1:2004 (2004): Eurocode 8 - Design of Structures for Earthquake Resistance-Part 1: General Rules, Seismic Actions and Rules for Buildings. European Committee for Standardization, CEN. 
[16] Celarec, D.; Ricci, P.; Matjaž, D. 2012: The Sensitivity of Seismic Response Parameters to the Uncertain Modelling Variables of Masonry-Infilled Reinforced Concrete Frames. Engineering Structures, Volume 35, pp. 165-177.

[17] Carvalho, E. C.; Coelho, E. (eds.) 2001: Seismic Assessment, Strengthening and Repair of Structures. ECOEST2-ICONS Report No.2, European Commission - "Training and Mobility of Researchers" Programme.

[18] EN 1991-1:2002 (2002): Eurocode 1 - Actions on structures - Part 1-1: General actions - Densities, selfweight, imposed loads for buildings. European Committee for Standardization, CEN.

[19] EN 1990-1:2002 (2002): Eurocode 0 - Basis of structural design. European Committee for Standardization, CEN.

[20] Crisafulli, F. J. 1997: Seismic Behavior of Reinforced Concrete Structures with Masonry Infills. Ph.D. Thesis, University of Canterbury, New Zealand, under direction of Professors Athol J. Carr and Robert Park.

[21] Panagiotakos, T. B.; Fardis, M. N. 1996: Seismic Response of Infilled RC Frames Structures. In 11WCEE, Eleventh World Conference on Earthquake Engineering, Paper No. 225.

[22] Ambraseys, N.; Smit, P.;S Igbjornsson, R.; Suhadolc, P.; Margaris, B. 2002:Internet-Site for European Strong-Motion Dana, European Commission, Research-Directorate General, Environment and Climate Programme.

[23] Iervolino, I.; Galasso, C.; Cosenza, E. 2009: REXEL: Computer Aided Record Selection for Code-Based Seismic Structural Analysis. Bulletin of Earthquake Engineering, Volume 8, pp. 339-362.

[24] FEMA 356 (Federal Emergency Management Agency) 2000: Prestandard and Commentary for the Seismic Rehabilitation of Buildings, Federal Emergency Management Agency, FEMA.

[25] Paulay, T.; Priestley, M. J. N. 1992: Seismic Design of Reinforced Concrete and Masonry Buildings. Wiley Interscience; 1st edition (March 1992).

[26] Takeda, T.; Sozen, M. A.; and Nielsen, N. N. 1970: Reinforced Concrete Response to Simulate Earthquakes. ASCE, Journal of the Structural Division, Volume 96, Issue 12, pp. 2557-2573. 